\title{
Age Cohort Effect on Financial Planning Preparation
}

\author{
Tan Hoe Kock ${ }^{1}$, Folk Jee Yoong ${ }^{2} \&$ Choong Kwai Fatt ${ }^{3}$ \\ ${ }^{1}$ GM Capital Group, Kuala Lumpur, Malaysia \\ ${ }^{2}$ Hickham Capital Group, Kuala Lumpur, Malaysia \\ ${ }^{3}$ Faculty of Business \& Accountancy, University of Malaya, Kuala Lumpur, Malaysia \\ Correspondence: Folk Jee Yoong, 4, Lorong 14/37E, 46100 Petaling Jaya, Selangor, Malaysia. E-mail: \\ yoong61@gmail.com
}

Received: January 10, 2012 Accepted: February 25, 2012 Online Published: May 24, 2012

doi:10.5539/jms.v2n2p18 URL: http://dx.doi.org/10.5539/jms.v2n2p18

\begin{abstract}
This paper examined age cohort effect on financial planning preparation. A total of 670 questionnaires were distributed with a 53.6\% return rate. Four hypotheses were analysed using hierarchical and stepwise regression analysis. The results revealed that age cohort variables made significant contribution to financial planning preparation as well as personal orientation towards retirement planning, particularly the younger age cohort. Age cohorts do affect personal orientation towards retirement planning with the confidence level making a significant impact. Current financial resources do have a strong positive impact on consumption for all age cohorts. On the other hand, no significant effect was found between age cohorts and current financial resources but older age cohorts were relatively more significant predictors.
\end{abstract}

Keywords: age cohort, financial resources, financial planning

\section{Introduction}

There is a growing trend around the world where the primary responsibility for providing an adequate retirement income has shifted from governments and employers to the individuals. Pension plans are shifting from the defined-benefit form to defined-contribution, in which plan participants must make investment decisions. With longevity increasing, replacing defined pension plans with defined contribution plans are making social security arrangements less certain. Increasingly, the very complex problem of saving and investing to provide for a secure retirement income is being transferred to the individuals who may not have either the knowledge or the training to handle the task.

For example, in the US, as a percentage of all private pension plans, the defined contribution plans increased from 66.8 percent to 92.3 percent in 1998 (Lusardi, 2006). The most obvious pitfall in self-retirement planning is that it shifts all retirement-planning risks - not saving enough, making poor investment choices, outliving savings - to untrained individuals. Even if investors follow the golden rules of investing - saving early and diligently, holding a broadly diversified investment mix, never tapping their savings until retirement - their success can still depend largely on the state of the world financial markets. A market meltdown or financial shock near the end of their working careers as witnessed in 2009 can wipe out their hard-earned savings and investments. Falling stock prices, lower interest rates and reduced dividends from previously stalwart companies may also reduce retirees' monthly income, requiring them to reduce spending or consider new ways to get income out of their diminished assets. For all age cohorts, the amount of financial resources they possess influence how much they will spend over their life cycle (Tan \& Folk 2011).

To be able to retire from active employment, people must have sufficient income to support themselves during the post-retirement period. Retirement income in Malaysia comes from a combination of different sources: pension income from the government for the civil service workers and members of the armed forces, and in the case of employees in the private sector, savings via withdrawals from the Employees Provident Fund (EPF), personal savings and investments, and support from family members. Previous studies of people in their fifties and early sixties have found that savings levels are insufficient and are not in congruent with their expected retirement age (Bernheim and Scholz, 1993; Lusardi, 1999). In many Asian countries, the commitment to familial support of the elderly has been found waning. In Japan, South Korea, and Taiwan, the percentage of elderly living with their children has declined substantially in recent years (Feeney \& Mason, 2001). 
In countries where social security provisions create strong incentives to retire, the retirement age may effectively be fixed, so that longer life spans lead to longer periods of retirement and greater pre-retirement savings. Social security rules in OECD countries create powerful financial incentives to retire at a particular age and that many workers appear to response to these incentives. In Taiwan, covered workers are eligible upon retirement to receive a lump sum payment based on their contributions to the social security system; the rules set an incentive for workers not to extend their working careers past 65 .

Two factors determine the retirement span - the retirement age and life expectancy. In a life-cycle savings context, retirement age determines the period for saving and for dissaving. Retirement age is important as it determines the duration of a person's working life and therefore how many years he has to earn income and build up the financial security for the future. This in turn determine the duration of the post-retirement period and the number of years the person will need to finance himself after his retirement. The increase in the retirement span among Malaysians reflects improved life expectancy - the typical Malaysian retiring today at say 55 years old will spend about 20 years in retirement. The individual's responsibility for retirement security includes making an accurate estimate of one's life span, apart from other important factors such as - retirement investment returns, future expenses in later years, and increases in the cost of living. Therefore, people face the prospect of having to support themselves for a long time on their accumulated retirement assets.

This paper has examined the extent Malaysians make financial preparations and their readiness for retirement, and the impact of expected retirement age on their financial planning preparation. A financial planning model derived from the life-cycle theories was tested, outlining personal demographics such work status, education, household composition, and income variables as life-cycle factors affecting the expectation and planning outcomes. Outcomes included financial literacy, retirement age, expected sources of retirement income, financial planning commencement, the propensity to save and investment strategies applied. This study further examines the issue by means of a cohort analysis to examine whether belonging to a particular group who engaged in retirement planning and having higher level financial literacy make a difference in attitude toward retirement and securing financial success in the post-retirement period among Malaysians.

\subsection{Social Security in Malaysia}

Malaysia's population, which is 28.31 million in 2009 (Dept. of Statistics, Malaysia) is expected to grow to about 33.4 million by year 2020. The current median age is less than 24 years. In term of age structure, the present population is still considered "youthful". However, with regard to the aged population (65 years and older), there has been a clear trend towards ageing population in Malaysia. The proportion of aged population is currently at 4.6 percent in 2009 compared to 3.7 percent in 1980. Given prevailing demographic trends, it is projected that by year 2020, those aged 65 and above will constitute about 6 percent (Table 1) of an estimated population of 33.4 million. In terms of absolute numbers, the population of older persons will increase from about one million in 2000 to 2.3 million by the year 2020 . This represents a more than two-fold increase within the span of 20 years, or an increase of 65,000 older persons per year.

Table 1. Population size and age structure Malaysia, $1980-2020$

\begin{tabular}{lcccc}
\hline & 1980 & 1991 & 2000 & 2020 \\
\hline $\begin{array}{l}\text { Total Population } \\
\text { (million) }\end{array}$ & 13.7 & 18.5 & 23.3 & 33.4 \\
$\begin{array}{l}\text { Average Annual Growth } \\
\text { Rate (\%) }\end{array}$ & 2.3 & 2.64 & 2.6 & 1.8 \\
& & & & \\
Age Structure (\%) & 39.6 & 37.2 & 33.1 & 30.5 \\
$0-14$ & 56.7 & 59.1 & 62.9 & 63.3 \\
$15-64$ & 3.7 & 3.7 & 4.0 & 6.1 \\
$65 \&$ above & & & & 57.8 \\
\hline
\end{tabular}

Source: Department of Statistics, Malaysia Eighth Malaysia Plan, 2001-2005

Table 1 indicates that the percentages of elderly people in the population are increasing whilst the number of young people is proportionately diminishing. Because of this increasing population of elderly people, research 
on retirement is crucial if Malaysian society is to manage and reduce the burden of poverty among retirees and the elderly population. Some of the demographic changes - rapid reduction in mortality, steady pace of fertility decline contributing to the consequent declining family size will impact the elderly persons. The decline in fertility and mortality levels in Malaysia has been consistent with the rapid economic growth that the country has been experiencing. As care for the older persons has traditionally been within the family system, further decline in the family size would ultimately reduce the number of family numbers available to care for their aged dependents. Care of the elderly within the family system is fast becoming a problem owing to the fact that the extended family structure is slowly being undertaken by nuclear family. Such problems are compounded as more women participate in the labour market and with increasing mobility of young family members.

With social and medical advancements, the average life expectancy in Malaysia has increased - from 47 years old in the 1950s to 72 years old for men and from 48.5 years old to 76 years old for women (Department of Statistics, Malaysia 2009). Better healthcare, availability of advanced medical technology, improved standards of living, higher education and literacy, have contributed to this change. In the absence of an old-age social security scheme in Malaysia, it is critical that people plan for their own financial retirement needs. More Malaysians are spending longer times of their lives in the post-retirement period although the retirement age for civil service had been increased from previously 55 years old to 58 years old. However, the retirement age for the private sector has largely remained unchanged at 55 years old.

The World Bank and most social security experts advocate a multi-tier framework of social security to provide for retirement income to the different segments of the population. The Bank had earlier suggested a three-pillar system of social security: (1) a publicly managed, unfunded Defined Benefit (DB) pillar which provides a core retirement income to nearly the entire workforce; (2) a mandatory savings tier and funded Defined Contribution (DC) pillar, designed to ensure that individuals do save for retirement, which would provide a supplement to social security; and (3) a voluntary private saving pillar representing income from private savings. The first tier is tax or contribution-financed redistributive tier with social insurance principles, designed to alleviate poverty and to provide protection to life-time poor. The second tier is the mandatory savings designed to ensure that individuals do save for retirement. The third is a tax-advantaged voluntary savings tier which can be used only for retirement (Asher, 2002). New developments and evidence have led the Bank to suggest a five pillar/tier framework (Holzmann and Hinz, 2005). The five-tier framework added Pillar Zero to provide basic pension or social assistance financed from the general budgetary revenues to cater to the lifetime poor in the community. Pillar Four recognizes the role of family, community, physical assets (housing) and post-retirement employment.

Malaysia has basically two types of retirement benefit plans: (1) a government pension system which is essentially a Defined Benefit (DB) scheme for the civil servants; and (2) a state-run provident fund, the Employees Provident Fund (EPF) for employees in the private sector. Research in behavioural economics suggests a breakdown of will power and self-control and often the lump sum EPF withdrawal is spent too quickly. Figure 1 shows mandatory savings scheme such as the EPF have two phases - accumulation phase during an individual's working career and the decumulation phase upon his retirement. In the accumulation phase, the rate of return on the savings accumulated and investments by the individual is important. In the decumulation phase, withdrawals of accumulated balances are drawn down on a "lump sum" basis. In the accumulation phase, the rate of return obtained on total balances accumulated by an individual has a crucial role to play. A low rate of return (nominal rate less inflation rate) implies that the final accumulated balances will be low, and vice versa. In the decumulation phase, the EPF provides for lump sum withdrawals of the accumulated balances rather than converting them to a periodic payment or an annuity (Asher, 2002). 


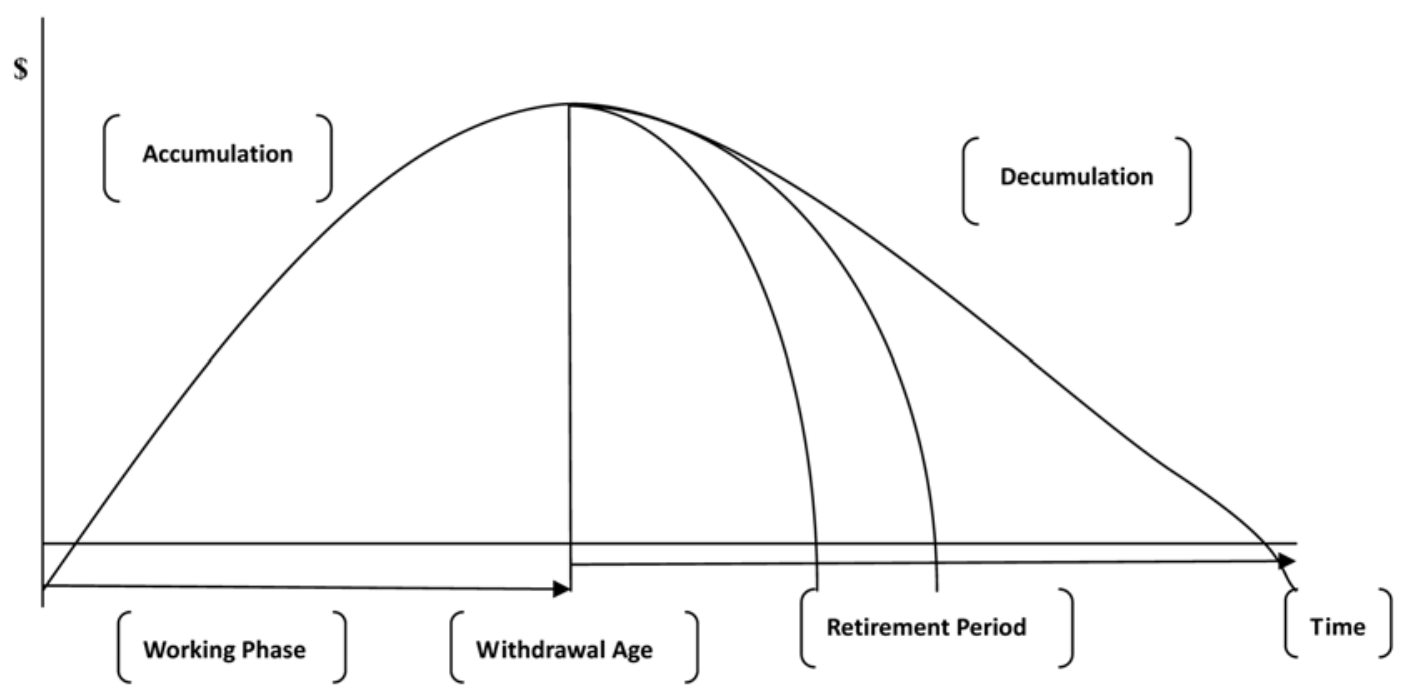

Figure 1. Accumulation and decumulation phases of provident funds cumulative balances

Source: Asher (2002)

The most important source of non-familial support for the elderly in Malaysia is the EPF. The EPF is a national provident fund set up in 1951. The EPF works on a DC formula and both employers and employees in the private sector contribute to the EPF at the current rate of $11 \%$ and $12 \%$ of monthly wages respectively. Upon reaching 50 years old, contributors are eligible and have the option to withdraw up to one third of their total balance in their EPF account. The balance of two third in their EPF account may be withdrawn in one lump sum upon reaching the age 55 years old. Individual contributors are permitted to withdraw a portion of his or her EPF contribution, prior to reaching to 55, for certain reasons. These include buying a house and meeting the medical costs of a serious disease. The total balance can be withdrawn in the following instances: death, incapacitation and emigration or attaining the age of 55. Benefits for retirees are linked directly to the contributions made by them and their employers during the period of employment, and the compounded annual dividend declared by the EPF. As a result, relatively highly-paid workers who pay more into their EPF accounts would have higher retirement accumulations than those who earn less and consequently pay less into their EPF accounts. Research in behavioural economics suggests a breakdown of will power and self-control and often the lump sum EPF withdrawal is spent too quickly. EPF lump-sum retirement benefits were found by the majority of retirees to be inadequate to sustain life after retirement; in most cases the benefits were exhausted within three years of receipt at age 55 (Beattie, 1998).

Table 2 shows the average savings of EPF members at 54 years of age, one year before entitlement to full withdrawal, is about RM50,000 (US\$14,285). With more than 90 percent of the country's total labour force employed in the private sector, this exclusive reliance on mandatory savings pillar in the private sector through the EPF results in the consequent lack of protection against longevity and inflation risks, lack of survivors' benefits, and inadequate replacement rates even at the time of retirement. This arrangement has also been found to be particularly discriminatory against women. Women as a group have lower exposure to labour force during their lifetime, and when they do, they as a group earn less than men and tend to live longer than men, and would require greater resources in old age. An important characteristic of retirement financing arrangements in Malaysia has been reliance on family, especially children. However, lower fertility rates, industrialisation, urbanisation, changing attitudes and values, expectations leading to more individualistic lifestyle are gradually undermining this reliance. 
Table 2. Average savings of EPF members at 54 years of age

\begin{tabular}{cccccc}
\hline Year & \multicolumn{2}{c}{ Active Members } & \multicolumn{2}{c}{ Inactive Members } & Average \\
& No. of Members & $\begin{array}{c}\text { Average } \\
\text { Savings }\end{array}$ & No. of Members & $\begin{array}{c}\text { Average } \\
\text { Savings }\end{array}$ & $\begin{array}{c}\text { Savings } \\
\text { (RM) } \\
\text { (RM) }\end{array}$ \\
\hline 2004 & 39,535 & 99,047 & 98,677 & 17,814 & \\
2005 & 42,881 & 106,933 & 107,534 & 18,876 & 41,051 \\
2006 & 47,438 & 114,402 & 108,097 & 21,478 & 49,820 \\
2007 & 48,501 & 121,163 & 124,094 & 20,574 & 48,840 \\
2008 & 53,022 & 132,539 & 130,653 & 21,894 & 53,834 \\
\hline
\end{tabular}

Source: EPF Annual Report 2008

\section{Literature Review}

Studies of retirement preparedness typically assume that people will retire at a fixed age. Earlier-than-expected retirement has been associated with adverse health and labour market shocks (Anderson et al., 1986; Disney and Tanner, 1999; Loughran et al., 2001). Barring injury or illness, the timing of retirement can be a matter of choice; workers can choose to when to retire, just as they choose how much to save.

The principal theories of saving are the life-cycle hypothesis (Modigliani and Brumberg, 1954; Ando and Modigliani, 1963), and the permanent income hypothesis (Friedman, 1957). Both of these theories assume that individuals and households try to smooth consumption over their lifetimes. The decisive difference between the two theories concerns the length of the planning period. For Friedman, this period is infinite, meaning that people also for their descendants unlike the Modigliani-Brumberg version, the planning period is finite meaning people save only for themselves.

In the face of labour income fluctuations over the course of life, these theories imply that saving rates will be uneven over the course of life. Basically, the life-cycle saving model assume that individuals live for three periods: when young, individuals borrow to finance current consumption, when they reach middle aged, they repay the loans taken out in the first half period of their life and save for retirement; when they get old and retire, they consume the assets accumulated in the second period of their life. The life-cycle hypothesis predicts that consumption in each period depends on expectations about lifetime income.

The literature on savings groups household savings motives into five categories:

1) Saving to provide resources for retirement - people save during their working years to finance their consumption after retirement. Life-cycle theory predicts that people save more in middle age and dissave in old age after retirement (Modigliani and Brumberg, 1954; Horioka, 2006).

2) Precautionary saving to finance unexpected losses of income - a hedge against uncertainty about the future; unemployment or sickness (Skinner, 1988; Zeldes, 1989; Carroll, 1992, 1997; Hubbard et al., 1995); liquidity constraints also make households increase precautionary saving (Zeldes, 1989; Browning and Lusardi, 1996).

3) Saving to smooth the availability of financial resources over time to maintain a more stable consumption profile (Carroll and Summers, 1989; Attanasio and Browning, 1995; Skinner, 1996).

4) Saving to finance expected large lifetime expenditure, that is "big-ticket" items (durable purchases), target savings (wedding, vacation, education); and

5) Saving for bequests - assets to bequeath to children and dependents. Bequests can be accidental because of the uncertainty regarding the date of death (Browning and Lusardi, 1996; Davies and Palumbo, 2001), strategic, or reduced consumption.

Lusardi $(1999,2006)$ find that planning has effects on both saving behaviour and portfolio choice. Households whose head has not planned for retirement accumulate much less than households whose head has done some planning. Previous studies have found that many households have limited resources until late in their life-cycle or start saving very late when it is not possible to accumulate much (Lusardi, 2006). The literature examining the financial well being of the baby-boom generation (Bernheim, 1993; Moore and Mitchell, 2000) has consistently show that baby boomers are not saving enough to maintain their current levels of consumption into their 
retirement years. Moore and Mitchell (2000) conclude that the majority of older households will not be able to maintain their current levels of consumption into retirement without additional saving.

Carroll (1992) reports that uncertainty helps to explain why consumption is highly correlated with income in the case of young consumers who expect their incomes to increase in the future but do not know by how much. Uncertainty also explains why the older population saves a positive amount as they face a lot of uncertainty regarding their length of life and health costs. Caroll and Summers (1989) obtained results which suggest that precautionary saving may account for a large portion of household wealth.

Carroll and Summers (1989) notice that the life cycle profiles of income and consumption tracked each other. Households headed by an individual with low education had a relatively flat profile for both income and consumption, while households headed by better educated individuals presented more of a hump shape. Carroll (1992) shows that if consumers are sufficiently impatient and their labour income is subject to both permanent and temporary shocks, they set consumption close to income. This model with impatient consumers under labour income uncertainty has been labeled "the buffer-stock model" of savings, because saving is kept to the lowest level compatible with the need to buffer negative income shocks. Carroll's buffer stock model can provide a rationale for the income tracking of consumption that was highlighted by Carroll and Summers (1989). Attanasio and Weber (1989) and Gourinchas and Parker (2002) clarify the role played by age-related changes in demographics and hump-shape age profile of labour income in generating income tracking for relatively young consumers. Hubbard, Skinner and Zeldes (1994 and 1995) show how precautionary motives interact with the insurance properties of social security in the US. Attanasio et al., (1999) investigates the interaction between demographics and precautionary savings, and highlighted the correlation between education and income; in the analysis education matters because of income and demographics age profiles are education/specific. Attanasio and Weber (1993) and Attanasio and Browning (1995) stressed the importance of demographics to explain observed patterns of consumption life cycle profiles.

One contrarian to Modigliani and Brumberg's (1954) life-cycle model which predicts that individuals save during their working lives to keep their consumption level constant once they retire, Hamermesh (1984) argue that consumers apparently do not save enough to achieve this aim. Households entering retirement with inadequate savings must cut their consumption level, contrary to the life-cycle model predictions. Banks et al., (1998) report evidence of a consumption fall around retirement (the retirement consumption puzzle) for the UK; Bernheim et al., (2001) for the US; and Battistin et al., (2008) for Italy. Bernheim, Skinner and Weinberg (2001) provide evidence that individuals enter retirement with inadequate savings. Smith (2006) stresses the importance of distinguishing between voluntary and involuntary retirement: a significant drop for food consumption is observed only for those who retire early because of poor health or job loss. Haider and Stephens (2004) estimate a smaller consumption drop for those who retire at the expected time. Fisher et al (2005) estimate a smaller drop for total expenditure than for food consumption. Aquiar and Hurst (2005 and 2007) and Hurd and Rohwedder (2006) stress that the drop in expenditure at retirement does not necessarily imply a drop in utility. For example, work-related expenditure such as transport to and from work, canteen meals and business clothing, are no longer needed. Home production of services (laundry, gardening, housecleaning, cooking) may become advantageous, and the extra leisure time allow consumers to shop more efficiently.

Deaton and Paxson (1997) and Paxson (1996) suggest that saving rates vary reasonably continuously with age, so that people of similar ages act in similar ways. A number of studies have examined the predictive power of individual date of retirement expectations and have found that these measures are strong predictors of future retirement dates (Disney and Tanner, 1999; Loughran et al., 2001). Deviations between expected and actual retirement ages are found to be correlated with wealth and health changes as well as marital transitions (Disney and Tanner, 1999). Maestas (2004) finds that many older workers who returned to work after retiring had planned on doing so (Haider and Stephens, 2004).

\section{Conceptual Framework}

The conceptual framework model is outlined in Figure 2 below. The conceptual model posits that several life-cycle factors affect retirement orientations, expectations and plans: family and work status, social location, household composition, consumption, and current financial resources. The life-course perspective links both proximal and distal forces to individuals' lived experiences. In this study, each model component is defined, previous relevant research for each component is summarised, and the hypothesised relationships between model components outlined below. The life-cycle factors affecting financial planning are summarised as they relate to these retirement outcomes. 
The age cohort is important for two reasons: the older the retirement age, the more years an individual will have in the work force, thus increasing the probability of having adequate financial resources for retirement. Longer employment may increase the types and amounts of retirement benefits. Retiring at an older age increases the number of years to accumulate savings for retirement; at the same time it reduces the number of years spent in retirement. Therefore, the higher the age cohort, the higher is the probability of having adequate financial resources for retirement. Early life advantages or disadvantages are recognized as cumulating over the life course, leading to different later-life experiences.

In this study, the relation between preferred and expected retirement age will be examined with reference to retirement plans. Are individuals who plan financially for retirement more likely to have congruence in their preferred and planned retirement age? What types of financial plans relate to greater congruence? Confidence in one's financial preparedness and savings encourages retirement at younger ages. Differences between expected and actual retirement ages may arise due to unforeseen circumstances, such as job redundancy, poor health, realization that one is not financially prepared to retire, and mental state of health. The life-course framework expands beyond consideration of time in an individual's life course to social and historical time as well.

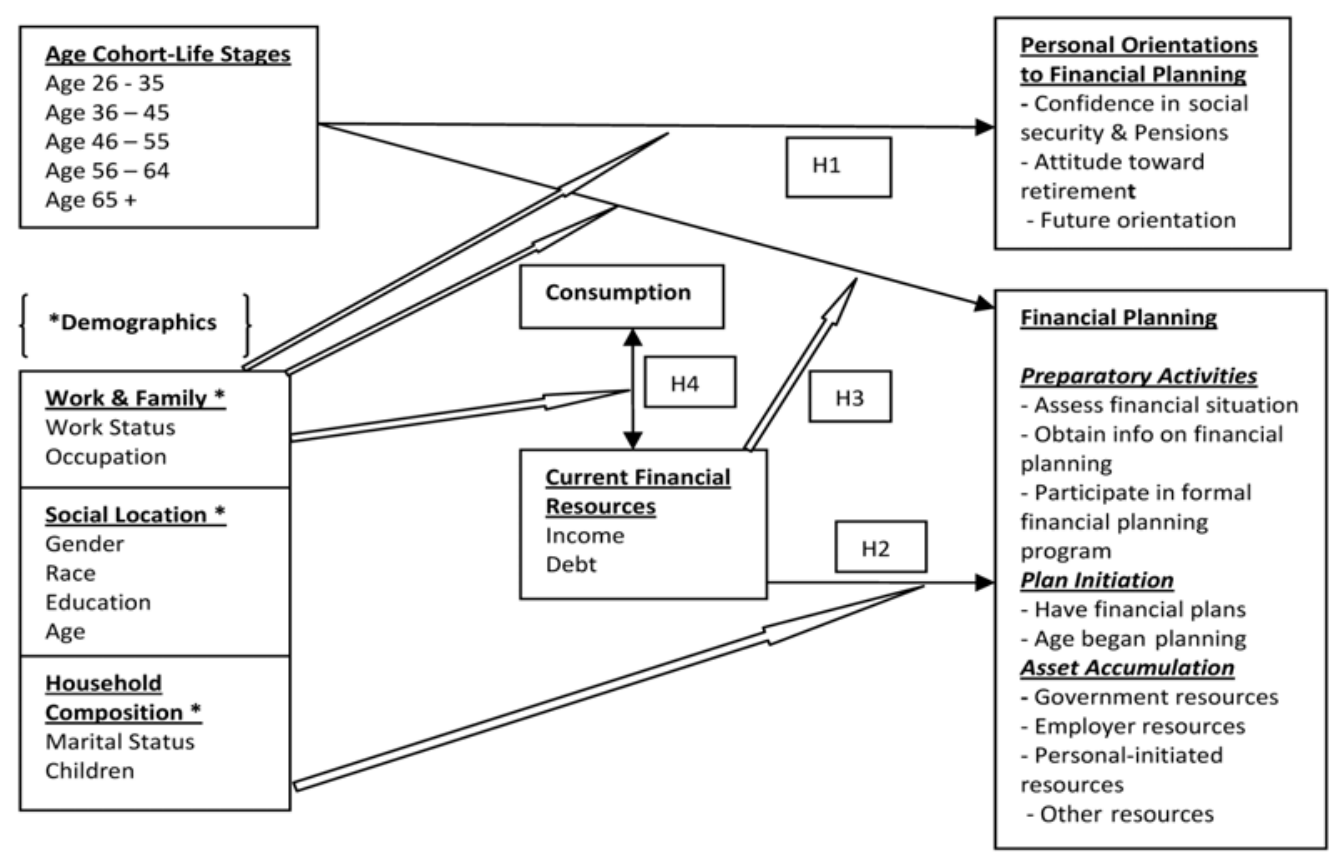

Figure 2. Conceptual framework of age cohort effects on financial planning

\subsection{Age Cohort}

A cohort refers to a group of people with unique shared experiences or characteristics. The concept of cohort (Ryder, 1965) has been recognised as an important way of assessing the influence of social change and historical circumstances on individuals (Elder and Caspi, 1990). This study examined whether belonging to a particular age cohort relates to differences in attitudes and financial preparation toward retirement. The six age cohorts are: 26-35, 36-45, 46-55, 56-64, and 65+. By having respondents at different stages of their life-cycle, this study examined the attitude and the general level of preparedness of Malaysians towards preparing for their retirement - focusing on how Malaysians plan and save for their retirement vis-à-vis the life-cycle theories. Therefore, it is hypothesised that age cohorts have a positive orientation towards retirement planning as well as financial planning preparation.

\subsection{Demographics}

\subsubsection{Work and Family}

The relationship between work and the family are critical factors to financial planning and retirement preparations. Most people spend a significant part of their adult lives in some form of employment and work. 
Through their job, people derive and build their value system, personal relationships, self-esteem and financial security. Employed persons are earning income and some are accumulating retirement savings and benefits. Unemployed persons, on the other hand, have to resort to living off their savings from past earnings, support from family members or to seek assistance from state social and welfare assistance. The accumulative effect of prolonged unemployment is lower or no retirement savings and income. Time spent out of the labour market that is devoted to marriage, family life, childbearing, caring for sick family members, and as a homemaker, impact financial planning for retirement due to discontinuity in work and income. Family responsibilities and commitments may involve work decisions such as choosing to work part-time to be able to spend more time with family. This is particularly critical in the case of female members of the family who typically assume more responsibility for caring for the family - giving up their own career opportunities to devote to their spouse as homemaker after marriage, devoting their time to look after their children and often times as caregivers to the elderly members of their family. These sacrifices can therefore undermine their own career advancements and in turn reduce their lifetime earnings, retirement savings, and financial independence.

\subsubsection{Social Location}

Socioeconomic background of cohorts constitutes social location which recognises existing social hierarchies and divisions that impact life experiences. Hierarchies and differences based on gender, race/ethnicity, and education create systems of disadvantage and privilege in society; which leads to considerable diversity in old age, consistent with the cumulative advantages and disadvantages hypothesis (Stoller and Gibson, 2000). Social location of individuals impacts retirement expectations and influence financial planning. The relationships between socioeconomic status with educational and occupation is an important indicator of the degree of social equity and the success of government policies aimed at reducing social inequality.

\subsubsection{Gender}

Gender issues are increasingly important in financial and retirement planning. Women make up about 50 percent of the population and about 36 percent of the labour force in Malaysia. While the economic position of women has improved over the years, women in the labour force are in the lower paid work, and women own only 15 per cent of business enterprises in Malaysia. Much of the economic policy had been directed towards distributional issues along ethnic lines, socio-economic groups, rather than gender-specific terms. There are gender differences in financial literacy, with women displaying a lower level of financial knowledge than men, particularly with regard to risk diversification (Lusardi and Mitchell, 2006). Marriage and children exert important influences on women's retirement (Vinick and Ekerdt, 1989). Childbearing and the need to work around family responsibilities can impact eventual retirement incomes (O'Rand and Landerman, 1984). As women are expected to live longer than men, having adequate financial resources to prepare for late life is critical.

\subsubsection{Race/Ethnicity}

Malaysia's demographics are represented by multiple ethnic groups. Malays and other Bumiputra groups make up $65 \%$ of the population, Chinese (26\%), Indians (8\%), and others (1\%). Racial categorisation is biological but its significance is mainly social. Ethnicity, while related to race, refers primarily to social and cultural forms of identification and self-identification. Race/ethnicity forms a significant part in the discourse concerning virtually any Malaysian social condition or issue including personal interaction in financial planning.

\subsubsection{Education}

Education and financial literacy is an important predictor of financial and retirement planning. The shift from defined benefit to defined contribution retirement plans means that individuals have to decide how much they need to save for retirement, how to invest their savings, and during the post-retirement period, how to allocate their portfolios and draw down their savings and income. Given the correlation between income and education, prior studies find evidence of a distinct pattern of higher saving for higher education groups (Bernheim and Scholz, 1993; Attanasio, 1993; Folk, et al., 2012). Bernheim and Scholz (1993), and Hubbard et al. (1994) have documented wide disparities in wealth holdings across different education groups.

\subsubsection{Household Composition}

Another demographic factor which is important for saving behaviour is the composition of the household. Compared to unmarried individuals, married couples report greater average wealth, more than remarried couples and singles. Since children increase household consumption requirements, the presence of children in the household and the timing of births may affect the length of the credit constrained period. Consequently, families with children would be expected to have lower retirement wealth than families without children. Households with many children may have larger positive late-career earnings shocks which may lead to higher optimal target 
replacement rates of pre-retirement income. Saving rates are higher for married couples with no children and lower for households with children, while lone parents have the lowest saving rate (Browning and Lusardi, 1996). Family ties is an important source of support in retirement years. Financial support from children helps to reduce the need to continue working in old age.

\subsection{Consumption}

Understanding consumption changes is important for individuals who are trying to assess how much income they will need in retirement, and what more they need to do before retirement to continue to enjoy the same level of economic well-being that they now experience (Fisher et al., 2005). In life cycle financial planning, it is consumption over a lifetime that is of primary interest to individuals and families, rather than wealth. Consumption is a measure of ultimate economic well-being (Shapiro, 2009).

The life-cycle hypothesis predicts that consumption remains smooth during the transition from work to retirement (Modigliani and Brumberg, 1954). According to the standard life-cycle model of consumption, forward looking agents will smooth their marginal utility of consumption across predictable income changes such as retirement. Current spending should reflect everything known about future income and interest rates. Hubbard, Skinner, and Zeldes (1995) and Carroll (1997) show that consumption and income age profiles are both significantly hump-shaped, and consumption tracks income over the early part of life. Moore and Mitchell (2000) conclude that the majority of older households will not be able to maintain current levels of consumption into retirement without additional savings. Similarly, about half of working middle class American households will not have fully funded retirements and some will run out of resources very shortly after retirement. Many households have limited resources until late in their life-cycle or start saving very late, up to the point where it is not possible to do much accumulation (Lusardi, 2006).

A fall in expenditure on retirement is expected as households no longer have to pay work-related costs, travel fares to and from work, and working clothes (Banks et al., 1998). Unexpected age and health-related consumption constraints can account for falling consumption and hence wealth accumulation during retirement among the retired elderly. Another possible explanation for falling expenditure is that individuals are able to substitute leisure for consumption after they retire (Banks et al., 1998). Bernheim et al., (2001) show that the drop in consumption is much sharper for those households that arrive at retirement with little wealth (Lusardi, 2006). Individuals faced with reduced income following retirement are forced to reduce consumption. Therefore, it is hypothesised that there is a relationship between current financial resources and consumption.

\subsection{Current Financial Resources}

If financial resources accumulated for retirement are sufficient to meet the financial needs of retirement, an individual may choose to retire. However, if the accumulated financial resources are insufficient, retirement may have to be deferred to a later date to allow time to accumulate additional financial resources or the retiree will have to accept a lower level of living in retirement. Several US studies on savings emphasise there is huge heterogeneity in household savings and wealth holdings, even among households close to retirement (Smith, 2006; Lusardi, 1999). Up to one quarter of the pre-retired population seem to under-save for retirement.

Income has been shown to be the main factor to determine both savings and asset holdings (Browning and Lusardi, 1996). Inheritances are sometimes overlooked as a source of retirement income, but they are important because they transfer residual savings or wealth across generations. The study postulates that 80 percent of Americans' household wealth originates from intergenerational transfers. Therefore, it is hypothesised that current financial resources influence retirement planning.

\subsection{Personal Orientations to Financial Planning}

As more Malaysians move into retirement, it is crucial to learn whether individuals and households planned for retirement and how they can execute these plans effectively. In as much as planning is an important predictor of saving and investment success, this may account for why household wealth holdings differ, and why some people enter retirement with very low wealth (Lusardi, 1999). Figure 2 outlines "personal orientations to financial planning" as one of the major outcomes of the conceptual framework. This comprise of: (1) confidence in the social security and pension systems; (2) attitude toward retirement; and (3) future orientation. This study will examine the effects of government policies on retirement saving behaviours and the individual's portfolio choice. Therefore, it is hypothesized that there is a relationship between expected retirement age and personal orientation towards retirement planning. 


\subsection{Confidence in Social Security and Pension}

The global trend is toward shifting responsibility for old age financial security from the state and employers to the individuals. Given the growth in defined contribution pensions and provident funds, and the concomitant dependency on the financial and capital markets performance, recent negative economic circumstances may cause individuals, especially those close to retirement age, to worry about their post-retirement financial security. Individuals who are less confident about the adequacy of their retirement savings and assets may have to start saving more, defer their retirement plans, or to seek new employment to supplement their post-retirement income.

\subsection{Attitude toward Retirement}

People spent thirty or more years of their adult life working, and retirement represents a sharp social, psychological, and economic break with life as they know it. People with negative views toward retirement are less likely to think about retirement (Fretz et al., 1989). Lusardi (1999) find that one-third of people (in the US) nearing retirement age have hardly thought about retirement; consequently they are less likely to save for retirement. Views and attitude toward retirement may affect plans for the transition. Individual attitude toward retirement is closely allied to the financial situation. The higher the expected income, the more favourable the attitude (Folk, 2011). Glasmer $(1976,1981)$ find that those who prepared for retirement may view the event more positively.

\subsection{Future Orientation}

Savings are inherently related to the future; and financial and retirement planning relate to expectations regarding a future event (Lusardi, 2006). People with a future orientation are more likely to anticipate events such as retirement (Aspinwall and Taylor, 1997), and more likely to think about and make preparations to achieve a successful outcome (Hershey and Mowen, 2000). Previous studies indicate that planning for retirement is positively related to satisfaction during retirement (Thompson, 1958; Glasmer, 1981).

\subsection{Financial Planning Outcomes}

The decision of how much to save for retirement is a complex one for an individual. It would require some understanding of several variables such as pensions, retirement benefits, basic fundamental economic and financial concepts including compound interest, inflation, financial markets, mortality tables, among others (Lusardi, 2006). In this study, financing planning for retirement is categorized into: (1) preparatory activities, (2) plan initiation, and (3) asset accumulation. Preparatory activities involve gathering information about or making assessments of their retirement needs, setting financial goals and objectives. Plan initiation refers to the age at which individuals begin making financial preparations for retirement. Asset accumulation encompasses the types of assets people anticipate they will have from the government, employers, and what they personally are accumulating for retirement.

\subsection{Financial Preparatory Activities}

The literature has shown that retirement planning is a powerful predictor of wealth accumulation. Those who have not thought about retirement have much lower wealth holdings than those who thought about retirement (Lusardi, 1999, 2000; Ameriks et al., 2002). Lack of planning has important consequences for savings and portfolio choice: those who do not plan are less likely to invest in stocks and tax-favoured assets (Lusardi, 2003). Those who plan have more than double the wealth of those who have not done any retirement planning (Lusardi, 2003; Lusardi and Mitchell, 2007a). Both Bernheim and Garrett (2003) and Lusardi (2003) find positive causal effects between attending firm sponsored retirement planning seminars and retirement wealth. These studies report evidence that planning can foster higher savings (Hurst 2004).

\subsection{Plan Initiation}

This study will examine when and at what age members of the various cohorts initiate financial planning for retirement, and whether people today are beginning to make financial plans for retirement earlier in life than did previous cohorts.

\subsection{Asset Accumulation}

Asset accumulation encompasses the accumulating of financial resources comprising of a combination of post-retirement income, housing wealth, and financial assets. An individual's savings/assets at retirement are influenced by the his choice of when to retire, labour and capital markets until retirement, expenditures until retirement, and expectations about income and expenditures following retirement (Haider and Stephens, 2004). 
The life-cycle theory suggests that age has an impact on savings. Individuals save while working in order to finance their consumption and income shortfalls during retirement. By saving early, younger people can take advantage of the compounding over time that investment affords. To show how well post-retirement income will allow retirees to maintain their standard of living, financial advisors use replacement rates - the ratio of post-retirement income to pre-retirement earnings. Because some expenses are reduced or eliminated in retirement (work-related expenses and saving for retirement), financial planners generally advise that retirees need 70-80 percent of their pre-retirement earnings to maintain a comparable standard of living in retirement. Most financial advisors adopt a pre-specified target replacement rate, proposing that households should ensure that retirement income exceeds 70 percent of pre-retirement income to finance consumption in retirement and therefore avoid a saving shortfall. Household's target replacement rate can be a function of household earnings and current wealth, and demographics.

Earnings shocks can have a substantial effect optimal replacement rate targets. A household that gets a positive late-in-career earnings shock would be expected to have replacement rates that are higher than the average of pre-retirement earnings. Conversely, a negative late-in-career shock could cause living standards to be revised downward in retirement. Medical expenses can also push up optimal target replacement rates and cause a substantial variation in the replacement rates prescribed. Malaysian retirees' potential sources of post-retirement income are pensions, EPF withdrawals, and income from assets (interest, dividends, rental income from real estate). While most retirees no longer have income from work, it has become increasingly common for some retirees to take up new employment, in which case employment income become a major source of income in retirement.

Inheritances are sometimes overlooked as a source of retirement income, but they are important because they transfer residual savings or wealth across generations. Individuals may save significant sums for the possibility of substantial end-of-life medical and nursing home expenses. If such medical problems do not arise, a bequest will arise.

The house is the largest single asset in most retired households (Dushi and Webb, 2004). Housing can serve a dual purpose: first, there is a consumption value from living in a home; second, housing is a store of wealth, from which the retiree can leave as a bequest. Most individuals value the option of remaining in their houses until declining health forces a move or a sale (Lusardi and Mitchell, 2006). Some financial planners point out how much retiree could save by "unlocking" their housing equity - either by downsizing through buying a smaller housing units or simply moving to a cheaper location. The literature suggests that housing boom caused people to increase their borrowing, to extract equity from their homes, and to raise their level of consumption. This suggests a strong positive relationship between fluctuations in house values and consumption, that increases in housing wealth increases consumption (Skinner, 1996; Davis and Polumbo, 2001; Belsky and Prakken, 2004; Case et al., 2005; and Carroll, Otsuka, and Slacelek, 2006). Similarly Muellbauer and Murphy (1997) find that house price increases and financial innovation stimulated a consumption boom in the UK. Homeowners and those who hold stocks and bonds have been found to have higher saving (Borsworth et al., 1991; Browning and Lusardi, 1996).

A summary of the hypotheses, derived from the above discussions, are examined as follow:

Hypothesis 1: Age cohort life cycle affect personal orientation towards retirement planning.

Hypothesis 2: Current financial resources have a positive impact towards financial planning.

Hypothesis 3: Current financial resources is a mediating factor of age cohorts having a positive impact on financial planning preparation.

Hypothesis 4: Current financial resources have a positive impact on consumption.

\section{Methodology}

This study uses a quantitative approach via a questionnaire survey to obtain primary information. Sample size was 359 Malaysians out of 670 questionnaires distributed. Non-probability sampling was used to using a quota sampling targeting the three major ethnic groups i.e. Malays, Chinese, and Indians. Only respondents over age 26 years old is targeted as there is higher chance that this age group has started thinking and making preparation for their retirement compared to a younger age group. Questionnaires were handed over to respondents by research assistants. The questions comprise of Likert-like questions and mainly closed-ended. Tests were carried out using the Statistical Package for Social Sciences (SPSS) for Windows. The significance level is set at 0.05 throughout the study. The use Cronbach alpha coefficient is used for Reliability Analysis (internal consistency). Alpha coefficient of above 0.6 is used. 
Constructs was tested using indexes which are multi-item instruments to measure a single concept with several attributes. The Factor Analysis tests were used to identify significant components which were included in the final equation; it was for finding factors within a large distribution of scores. Items with primary factor loadings greater that 0.4 was judged sufficient.

Regression Analysis was used to measure the amount of variance explained in the dependent variable by the predictors. Multiple regression tests were carried out for all the hypotheses as there are several independent variables involved. Checks were carried out for mediating effect on some variables using hierarchical regression tests. Hierarchical regression was used to test the significance of each independent variable as reflected in the conceptual framework. Stepwise regression were used in Hypotheses 1, 3 and 4. It was used to examine the best combinations for independent variables until the R-squared does not increase by a significant amount. Descriptive Analysis was first examined, followed by multiple regression analysis.

\section{Data Analysis and Findings}

\subsection{Descriptive Analysis}

Table 3 below depicts the respondents' demographic characteristics such as age, gender, ethnicity, and marital status, level of education, health, average life expectancy, type of employment, house ownership and children. Out of 359 respondents that responded, majority of them were from the age ranges between 26 and 45 years old. Most of the respondents were Chinese followed by Malays. Indians made up of the minority. More than $60 \%$ of the respondents were married while the remaining $32.7 \%$ were single, widow, separated or divorced. More than $75 \%$ of the respondents have tertiary education. Overall respondents and their spouses have good or excellent health. It shows that most people take great care of their health. Usually, a big sum of our retirement savings is spent on medical expenditure. Therefore, health plays an important role in retirement planning. Perception of life expectancy is between 65 to 75 years of age. A majority of the respondents are homeowners and only $19.7 \%$ are renting or staying with family or friends. Homeownership accounts for a large part of an individual's expenditure and has a significant impact on retirement planning. Most respondents have an average of one to three children. Only a small percentage of the respondents have four and above. More children will imply extra expenses in a household in term of education, medical and daily necessities.

Table 3. Survey results - descriptive analysis

\begin{tabular}{|c|c|c|c|c|c|c|c|c|c|c|c|}
\hline Age & $26-35$ & $36-45$ & $46-55$ & $56-65$ & $>66$ & Gender & Male & Female & & & \\
\hline$\%$ & 49.2 & 36.1 & 6.6 & 4.9 & 3.2 & $\%$ & 36.1 & 63.9 & & & \\
\hline Ethnicity & Malay & Chinese & Indian & Others & & $\begin{array}{l}\text { Marital } \\
\text { Status }\end{array}$ & Married & Single & Others & & \\
\hline$\%$ & 27.9 & 57.4 & 13.1 & 1.6 & & $\%$ & 65.6 & 26.2 & 8.1 & & \\
\hline Education & No & Primary & Secondary & Tertiary & & Health & Excellent & Good & Fair & Poor & \\
\hline Level & School & & & & & & & & & & \\
\hline$\%$ & 1.6 & 1.6 & 18.1 & 78.7 & & $\%$ & 23.0 & 59.0 & 14.8 & 3.3 & \\
\hline Spouse & Excellent & Good & Fair & Poor & & Life & $65-70$ & $71-75$ & $76-80$ & $>80$ & \\
\hline Health & & & & & & Expectancy & & & & & \\
\hline$\%$ & 19.7 & 44.3 & 32.8 & 3.3 & & $\%$ & 23.0 & 37.7 & 27.9 & 11.4 & \\
\hline $\begin{array}{l}\text { Home } \\
\text { Ownership }\end{array}$ & Own & Rent & & & & $\begin{array}{l}\text { No. of } \\
\text { Children }\end{array}$ & 0 & 1 & 2 & 3 & $>3$ \\
\hline$\%$ & 73.8 & 26.2 & & & & $\%$ & 39.4 & 18.0 & 19.7 & 14.8 & 8.1 \\
\hline
\end{tabular}




\subsection{Hypothesis Testing}

Hypothesis 1: Age Cohort vs. Personal Orientation To Retire Plan (Multiple Regression).

Hypothesis 1.1: H0 - Age cohort DG1a does not affect personal orientation towards retirement planning.

DAge1 was significant at the 0.05 level $(\Delta \mathrm{R} 2=.383, \Delta \mathrm{F}=2.537, \mathrm{p}<.05)$. Hence, the null hypothesis was rejected.

Hypothesis 1.2: $\mathrm{H} 0$ - Age cohort DG1b does not affect personal orientation towards retirement planning.

DAge2 was significant at the 0.05 level $(\Delta \mathrm{R} 2=.387, \Delta \mathrm{F}=2.535, \mathrm{p}<.05)$. Hence, the null hypothesis was rejected.

Hypothesis 1.3: H0 - Age cohort DG1c does not affect personal orientation towards retirement planning.

DAge3 was significant at the 0.05 level $(\Delta \mathrm{R} 2=.374, \Delta \mathrm{F}=2.376, \mathrm{p}<.05)$. Hence, the null hypothesis was rejected.

Hypothesis 1.4: $\mathrm{H} 0$ - Age cohort DG1d does not affect personal orientation towards retirement planning.

DAge4 was not significant at the 0.05 level $(\Delta \mathrm{R} 2=.259, \Delta \mathrm{F}=1.191, \mathrm{p}=.33)$. Hence, the null hypothesis was accepted.

Hypothesis 1.5: H0 - Age cohort DG1e does not affect personal orientation towards retirement planning.

DAge5 was not significant at the 0.05 level $(\Delta \mathrm{R} 2=.125, \Delta \mathrm{F}=.396, \mathrm{p}=.929)$. Hence, the null hypothesis was accepted.

Hypothesis 2: Current Financial Resources vs. Financial Planning (Stepwise Regression).

Hypothesis 2: $\mathrm{H} 0$ - Current financial resources does not have a positive orientation towards financial planning.

The regression tests showed that DLEAGE and DSAGE was a relatively significant predictor of the current financial resources. The results have indicated that the regression coefficient associated with DLEAGE1 variable was significant when first entered in Step $1(b=-.417, p<0.05)$. After the DSAGE1 variable was entered in Step $2(\mathrm{~b}=0.379, \mathrm{p}<0.05)$, the regression coefficient associated with DLEAGE1 became more significant $(\mathrm{b}=$ $-.435, \mathrm{p}<0.05$ ). This has indicated no mediating effect, which was significant. Hence, the null hypothesis was rejected.

Hypothesis 3: Current financial resources and age cohort vs. Fin Plan Preparation (Hierarchical Regression).

Hypothesis 3.1: H0 - Current financial resources is not a mediating factor of Age cohort DAgel having a positive impact on financial planning preparation.

The Current financial resources variables were not significant at the 0.05 level $(\Delta \mathrm{R} 2=.034, \Delta \mathrm{F}=.317, \mathrm{p}=.732)$. The regression tests showed that Current Financial Resources Index was not a significant predictor of expected retirement age DG1a. Hence, the null hypothesis was accepted.

Hypothesis 3.2: H0 - Current financial resources is not a mediating factor of Age cohort DAge2 having a positive impact on financial planning preparation.

The Current financial resources variables were not significant at the 0.05 level $(\Delta \mathrm{R} 2=.055, \Delta \mathrm{F}=.528, \mathrm{p}=.598)$. The regression tests showed that Current Financial Resources Index was not a significant predictor of expected retirement age DG1b. Hence, the null hypothesis was accepted.

Hypothesis 3.3: H0 - Current financial resources is not a mediating factor of Age cohort DAge3 having a positive impact on financial planning preparation.

The Current financial resources variables were not significant at the 0.05 level $(\Delta \mathrm{R} 2=.061, \Delta \mathrm{F}=.582, \mathrm{p}=.569)$. The regression tests showed that Current Financial Resources Index was not a significant predictor of expected retirement age DG1c. Hence, the null hypothesis was accepted.

Hypothesis 3.4: H0 - Current financial resources is not a mediating factor of Age cohort DAge4 having a positive impact on financial planning preparation.

The Current financial resources variables were not significant at the 0.05 level $(\Delta \mathrm{R} 2=.120, \Delta \mathrm{F}=1.233, \mathrm{p}=.315)$. The regression tests showed that Current Financial Resources Index was not a significant predictor of expected retirement age DG1d. Hence, the null hypothesis was accepted.

Hypothesis 3.5: H0 - Current financial resources is not a mediating factor of Age cohort DAge5 having a positive impact on financial planning preparation. 
The Current financial resources variables were not significant at the 0.05 level $(\Delta \mathrm{R} 2=.120, \Delta \mathrm{F}=1.233, \mathrm{p}=.315)$ The regression tests showed that Current Financial Resources Index was not a significant predictor of expected retirement age DG1d. Hence, the null hypothesis was accepted.

Hypothesis 4: Current Fin Resources and Demographic vs. Consumption

Hypothesis 4: H0 - Current financial resources does not have a positive impact on consumption.

The regression tests showed that Save Index and Inc Index was a significant predictor of Consumption at the 0.01 level $(\Delta \mathrm{R} 2=.403, \Delta \mathrm{F}=6.085, \mathrm{p}<.01)$. Hence, the null hypothesis was rejected. When demographics were added, the regression equation was more significant $((\Delta \mathrm{R} 2=.596, \Delta \mathrm{F}=206.046, \mathrm{p}<.001)$. There were several demographic variables that were significant at the 0.001 level including Dage2, Dage3, Dage4, Dage5, DChild1, DChild2, DSAGE1, DSAGE2, DSAGE3, DLEAGE1, DLEAGE2, DLEAGE3 and DLEAGE4.

[Note: DLEAGE $=$ Estimated Life Expectancy; DSAGE $=$ Spouse Age; DG $=$ Expected Retirement Age; Nos after abbreviation: $1=$ Age 26-35; 2 = Age 36-45; 3 = Age 46-55; $4=$ Age 56-65; $5=$ Age $>66$; DChild $=$ No. of children]

\section{Concluding Remarks}

The survey results indicate that current financial resources do have an impact on positive orientation towards retirement planning particularly for those in the younger age group. This study has provided many insights about the retirement expectations and preparations of different people and structural, work, family, race and personal factors affecting their retirement outcomes. The younger age cohorts usually have very little savings so they may be planning to save or increase their disposable income for a better standard of living in later years. However, it is not very clear if their intention to save more is purely to improve their standard of living during mid life or saving for their retirement. Further research can be carried out for this life cycle path looking at their propensity to save and the sort of investment strategies applied.

Expected retirement age does not have any positive orientation towards current financial resources for all age cohorts. This may be because the respondents felt that if there is a shortfall in financial resources at the present time; they will make up for any shortfall in later years, hence the apathetic attitude. Expected retirement age does affect personal orientation towards retirement planning with the confidence level making a significant impact. Confidence level is important as it strengthens people expectations for the future. Confidence level can be brought about by many external factors such as the current economic situation, performance of the company the respondent is working for, and their income and savings level.

Expected retirement age for all age cohorts does affect financial planning preparation. For each age cohort, when one expects to retire can influence how they prepare for their retirement. This may entail adjusting their consumption pattern of their life cycle. Current financial resources do have a strong positive impact on consumption for all age cohorts. For all age cohorts, how much financial resources they have influence how much they will spend over their life cycle. Marketers have employed this strategy of life cycle consumption to plan for their marketing strategy of targeting consumers.

Thus far, this paper has examined the extent Malaysians make financial preparations and their readiness for retirement, and looked at age cohort's life cycle on their financial planning preparation. The financial planning model derived from the life-cycle theories showed positive influences from the personal demographics such as work status, education, household composition, and income variables as life-cycle factors affecting the expectation and planning outcomes. This study has also examined the issues by means of a cohort analysis to examine whether belonging to a particular group who engaged in retirement planning and having higher level financial literacy make any difference in attitudes toward retirement. The education variable did make a significant impact. This research is a long-term, even life-long, process that intensifies when people near retirement age.

\section{References}

Aguiar, M., \& Hurst, E. (2005). Consumption vs. Expenditure. Journal of Political Economy, 113(5), 919-948. http://dx.doi.org/10.1086/491590

Ameriks, J., Caplin, A., \& Leahy, J. (2002). Retirement Consumption: Insights from a Survey. NBER Working Paper No. 8735.

Anderson, K. H., Burkhauser, R. V., \& Quinn, J.F. (1986). Do Retirement Dreams Come True? The Effect of Unanticipated Events on Retirement Plans. Industrial and Labor Relations Review, 39(4), 518-26. http://dx.doi.org/10.2307/2523244 
Ando, A., \& Modigliani, F. (1957). Tests of the life cycle hypothesis of saving: Comments and suggestion. Oxford Institute of Statistics Bulletin, 19, 99-124.

Ando, A., \& Modigliani, F. (1963). The life-cycle hypothesis of saving: Aggregate implications and tests. American Economic Review, 53, 55-84.

Aquiar, M., \& Hurst, E. (2007). Lifecycle Prices and Production. American Economic Review, 97(5), 533-1559.

Asher, M. G. (2002). Behavioral Economics and Retirement Well-being in Asia. International Center for Pension Research, Research Report No. 4-2002.

Aspinwall, L., \& Taylor S. (1997). A stitch in time: Self-regulation and proactive coping. Psychological Bulletin, 121(3), 417-436. http://dx.doi.org/10.1037/0033-2909.121.3.417

Attanasio, O.P., \& Browning, M. (1995). Consumption over the life cycle and over the business cycle. American Economic Review, 85(5), 1118-37.

Attanasio, O. P., \& Weber, G. (1989). Intertemporal Substitution, Risk Aversion and the Euler Equation for Consumption. Economic Journal, 99(395), 59-73. http://dx.doi.org/10.2307/2234070

Attanasio, O. P., \& Weber, G. (1993). Consumption Growth, the Interest Rate and Aggregation. Review of Economic Studies, 60(3), 631-49. http://dx.doi.org/10.2307/2298128

Attanasio, O. P., Banks, J., Meghir, C., \& Weber, G. (1999). Humps and Bumps in Life-Time Consumption. Journal of Business and Economic Statistics, 17(1), 22-35. http://dx.doi.org/10.2307/1392236

Banks, J., Blundell, R., \& Tanner, S. (1998). Is There a Retirement-Savings Puzzle? American Economic Review, 88(4), 769-788.

Battistin, E., Brugiavini, A., Rettore, E., \& Weber, G. (2008). The retirement consumption puzzle: Evidence from a regression discontinuity approach. IPS WP08/05.

Beattie, R. (1998). Pension systems and prospects in Asia and the Pacific. International Social Security Review, 51(3), 63-87. http://dx.doi.org/10.1111/1468-246X.00017

Belsky, E., \& Prakken, J. (2004). Housing wealth effects: Housing's impact on wealth accumulation, wealth distribution, and consumer spending. Working Paper W04-13, Cambridge, MA: Joint Center for Housing Studies of Harvard University.

Bernheim, B. D., Skinner, J., \& Weinberg, S. (2001). What accounts for the variation in retirement wealth among US households? American Economic Review, 91(4), 832-857. http://dx.doi.org/10.1257/aer.91.4.832

Bernheim, B. D., \& Scholz, J. K. (1993). Do Americans save too little? Business Review, 9(10), 3-21.

Bosworth, B., Burtless, G., \& Sabelhaus, J. (1991). The decline in saving: Some microeconomic evidence. Brookings Papers on Economic Activity, 1, 183-256. http://dx.doi.org/10.2307/2534640

Browning, M., \& Lusardi, A. (1996). Household saving: Micro theories and micro facts. Journal of Economic Literature, 34(4), 1797-1855.

Carroll, C., Otsuka, M., \& Slacelek, J. (2006). How large is the housing wealth effect? A new approach. Mimeo.

Carroll, C. D. (1992). The buffer-stock theory of saving: Some macroeconomic evidence. Brookings Papers on Economic Activity, 1992(2), 61-156. http://dx.doi.org/10.2307/2534582

Carroll, C. D. (1997). Buffer-stock saving and the life cycle/permanent ncome hypothesis. The Quarterly Journal of Economics, 112(1), 1-55. http://dx.doi.org/10.1162/003355397555109

Carroll, C. D., \& Summers, L. (1989). Consumption growth parallels income growth: Some new evidence. NBER Working Papers 3090.

Case, K. E., Quigley, J. M., \& Shiler, R. J. (2005). Comparing wealth effects: The stock market versus the housing market. Advances in Macroeconomics, 5(1), Article 1.

Davis, M., \& Palumbo, M. (2001). A primer on the economics and time series econometrics of wealth effects. Federal Reserve Finance and Economics Discussion Series 2001-9. Washington, DC: Federal Reserve Board.

Deaton, A., \& Paxson C. (2000). Growth and saving among individuals and households. Review of Economis and Statistics, 82(2), 212-233. http://dx.doi.org/10.1162/003465300558740 
Deaton, A., \& Paxson, C. (1997). The effects of economic and population growth on national savings and inequality. Demography, 34, 97-114. http://dx.doi.org/10.2307/2061662

Disney, R., \& Tanner, S. (1999). What can we learn from retirement expectations data? The Institute for Fiscal Studies. Working Paper Series No. W99/17.

Dushi, I., \& Webb, A. (2004). Household annuitisation decisions: Simulations \& empirical analyses. Journal of Pension Economics \& Finance, 3(2). http://dx.doi.org/10.1017/S1474747204001696

Elder, G.H., \& Caspi, A. (1990). Studying lives in a changing society: Sociological \& personological explorations. In A. Rabin, R. Zucker, R. Emmons \& S. Frank (Eds.), Studying Persons \& lives (pp. 201-247). New York: Springer Publishing Company.

Feeney, G., \& Mason, A. (2001). Population in East Asia. In Andrew Mason (Ed.), Population Change \& Economic Development in East Asia: Challenges Met, Opportunities Seized. Stanford: Stanford University Press.

Fisher, J., Johnson, D. S., March, J., Smeeding, T. M., \& Torrey, B. B. (2005). The retirement consumption conundrum: Evidence from a consumption survey. Centre for Retirement Research, Boston College.

Folk, J. Y. (2011). Retirement Financial Planning by Malaysian Chinese. Lambert Academic Publishing AG \& Co., Cologne, Germany.

Folk, J. Y., Beh, L. S., \& Baranovich, D. L. (2012). Financial education: Determinant of retirement planning in Malaysia. E3 Journal of Business Management \& Economics, 3(2), 69-78.

Fretz, B. R., Kluge, N. A., Ossana, S. M., Jones, \& Merikangas, M. W. (1989). Intervention strategies for reducing pre-retirement anxiety \& depression. Journal of Counselling Psychology, 36, 310-317. $\mathrm{http}: / / \mathrm{dx}$. doi.org/10.1037/0022-0167.36.3.301

Friedman, M. (1957). A theory of the consumption function. Princeton, NJ: Princeton University Press.

Glasmer, F. D. (1981). Predictors of retirement attitudes. Ageing \& Work, 4, 23-29.

Gourinchas, P. O., \& Parker, J. A. (2002). Consumption over the life cycle. Econometrica, 70(1), 47-89. http://dx.doi.org/10.1111/1468-0262.00269

Haider, S. J., \& Stephens, M. (2004). Is there a retirement-consumption puzzle? Evidence using subjective retirement expectations. NBER Working Paper No. 10257.

Hamermesh, D. S. (1984). Consumption during retirement: The missing link in the life-cycle. Review of Economics \& Statistics, 66(1), 1-7. http://dx.doi.org/10.2307/1924689

Hershey, D. A., \& Mowen, J. C. (2000). Psychological determinants of financial preparedness for retirement. The Gerontologist, 40(6), 687-697. http://dx.doi.org/10.1093/geront/40.6.687

Holzmann, R., \& Hinz, R. (2005). Old age income support in the 21st century. Washington, D.C.: The World Bank. http://dx.doi.org/10.1596/0-8213-6040-X

Horioka, Y. (2006). Do the elderly dissave in Japan? Osaka University. Retrieved from www2.e.u-tokyo.ac.jp/ seido/output/Horioka/horioka001.pdf

Hubbard, R. G., Skinner, J., \& Zeldes, S. P. (1994). The importance of precautionary motives in explaining individual \& aggregate saving. Carnegie-Rochester Conference Series on Public Policy, 40, 59-125. http://dx.doi.org/10.1016/0167-2231(94)90004-3

Hubbard, R. G., Skinner, J., \& Zeldes, S. P. (1995). Precautionary saving \& social insurance. Journal of Political Economy, 103(2), 360-99. http://dx.doi.org/10.1086/261987

Hurd, M., \& Rohwedder, S. (2006). Some answers to the retirement-consumption puzzle. NBER Working Paper 12057.

Loughran, D., Constantijn, P., Hurd, M., \& Reti, M. (2001). Retirement planning. R\& Munuscript.

Lusardi, A. (1999). Information, expectations, \& savings. In Henry Aaron (Eds.), Behavioral Dimensions of Retirement Economics (pp. 81-115). New York: Brookings Institution Press/Russell Sage Foundation.

Lusardi, A. (2006). Planning \& financial literacy: How do women fare? MRRC Working Paper 2006-136. University of Michigan.

Lusardi, A., \& Mitchell, O. S. (2006). Financial literacy \& planning: Implications for retirement wellbeing. Retrieved from http://www.dartmough.edu/ alusardi/Papers/FinancialLiteracy.pdf. 
Maestas, N. (2004). Back to work: Expectations \& realizations of work after retirement. Michigan Retirement Research Center: Working Paper 2004-085.

Modigliani, F., \& Brumberg, R. (1954). Utility analysis \& the consumption function: An interpretation of cross-section data. In K. Kurihara (Ed.), Post Keynesian Economics. Rutgers University Press, New Brunswick, NJ.

Moore, J., \& Mitchell, O. (2000). Projected retirement wealth \& saving adequacy. In Olivia Mitchell, Peter Hammond \& Anna Rappaport (Eds.), Forecasting Retirement Needs \& Retirement Wealth (pp. 68-94). Philadelphia: University of Pennsylvania Press.

Muellbauer, J., \& Murphy, A. (1997). Booms \& Busts in the UK housing market. Economic Journal, 107(445), 1701-1727. http://dx.doi.org/10.1111/j.1468-0297.1997.tb00076.x

O'R\&, A. M., \& Landerman, L. R. (1984). Women's \& men's retirement income: Early family role effects. Research on Aging, 6(1), March, 25-44. http://dx.doi.org/10.1177/0164027584006001002

Paxson C. H. (1996). Saving \& growth: Evidence for micro data. European Economic Review, 40, 255-288. http://dx.doi.org/10.1016/0014-2921(95)00063-1

Ryder, N. B. (1965). The cohort as a concept in the study of social change. American Sociological Review, 30(6), 843-861. http://dx.doi.org/10.2307/2090964

Skinner, J. (1996). Is housing wealth a sideshoe? In David A. Wise (Ed.), Advances in the Economics of Aging. Chicago, IL: University of Chicago Press (for NBER).

Smith, S. (2006). Can the retirement puzzle be resolved? Evidence from UK panel data. Economic Journal, 116(510), C130-C148. http://dx.doi.org/10.1111/j.1468-0297.2006.01080.x

Stephen P. (1989). Consumption \& liquidity constraints: An empirical investigation. Journal of Polictical Economy, 97(2), 305-46.

Stoller, E. P., \& Gibson, R. (2000). Advantages of using the life course framework in studying aging. In E. P. Stoller \& R. Gibson (Eds.), Worlds of difference: Inequality in the aging experience (pp. 19-33). Thous \& Oaks, CA: Pine Forge Press.

Tan, H. K., \& Folk, J. Y. (2011). Expected retirement age: A determinant of financial planning preparation in Malaysia. African Journal of Business Management, 5(22), 9370-9384.

Tan, H. K., \& Folk, J. Y. (2011). Knowing when to retire: The first step towards financial planning in Malaysia. Educational Gerontology, 37(10), 854-884. http://dx.doi.org/10.1080/03601277.2010.485008

Thompson, W.E. (1958). Pre-retirement anticipation \& adjustment in retirement. Journal of Social Issues, 14, 35-45. http://dx.doi.org/10.1111/j.1540-4560.1958.tb01404.x

Vinick, B. H., \& Ekerdt, D. J. (1989). Retirement \& the family. Generations, 13(2), 53-56. 